\title{
Constructing Credibility: How Aggrandizement Helps Perform an Identity of Legitimacy and Self-Worth in a Creative Industry
}

\author{
David Schreiber \\ Belmont University \\ Alison Rieple \\ University of Westminster
}

This paper was presented at the 2019 International Summit of the

Music \& Entertainment Industry Educators Association

March 21-23, 2019

$\underline{\text { https://doi.org/10.25101/19.35 }}$

\begin{abstract}
This study contributes to an understanding of the role of aggrandizement in constructing a credible identity within an industrial context characterized by uncertainty and risk-taking, the popular music industry. Specifically, this paper focuses on the extent to which creative personalities draw on real and imaginary justifications to portray themselves as having attained greater success than they have actually achieved in order to construct a credible identity both to themselves and to others. As a positive self-illusion lends psychological benefits as well as the means to achieving self-fulfilling high performance, we conclude that aggrandizement may enhance the individual's performance both professionally and personally. Although the extant literature highlights how positive self-illusions can influence identity construction, the role aggrandizement plays in this process within a creative context does not appear to have been researched.
\end{abstract}

Keywords: aggrandizement, identity construction, self-illusion popular music, music industry, creative industries

David Schreiber is an Assistant Professor and Chair of the Creative \& Entertainment Industries program at Belmont University in Nashville, Tennessee. His research interests include decision-making practices within music industry micro-enterprises, identity construction within creative industries, and the role of strategic sexual performance as it is used in creative and cultural industry organizations. $\mathrm{He}$ recently co-authored a textbook with Paul Saintilan on Managing Organizations in the Creative Economy: Organizational Behavior for the Cultural Sector through Routledge Publishing in the U.K. Furthermore, David is a member of the Academy

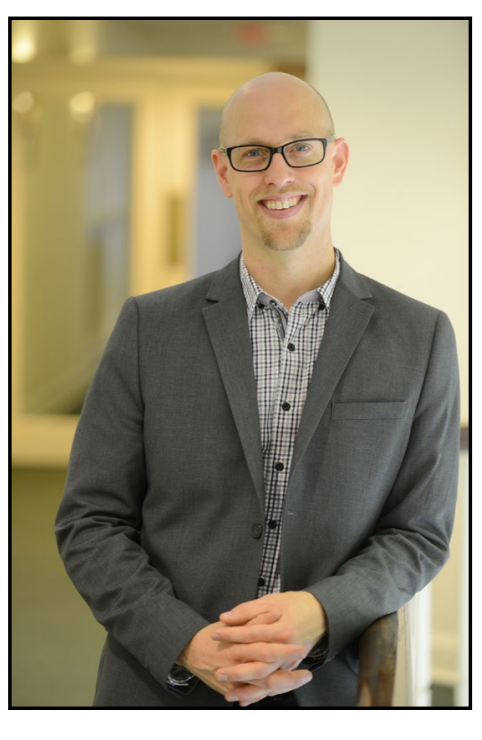
of Management (AOM), European Group of Organization Studies (EGOS), the Music and Entertainment Industry Educators Association; is a reviewer for the Journal of Small Business Management, has served as an Associate Editor of the MEIEA Journal.

Alison Rieple is Professor of Strategic Management at the University of Westminster and Director of IDEaS, WBS' Innovation Design Entrepreneurship and Strategy Research Group. After leaving university (with a degree in music) Alison worked in the probation service, latterly running a probation hostel for serious male offenders. Clearly a glutton for punishment, she left to do an MBA and then a $\mathrm{PhD}$ at Cranfield University. Since then she has worked for the University of Westminster, for nine years as Director of Research at Harrow Business School. She was appointed a Professor in 2002. 


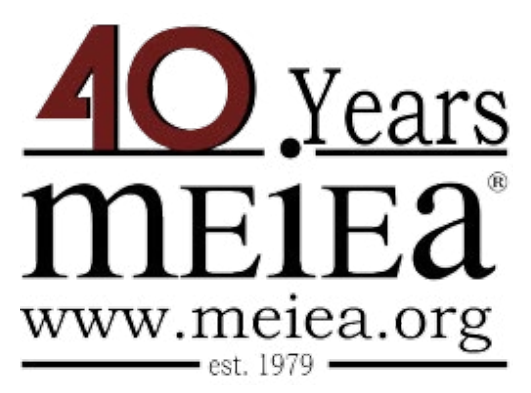

\section{PROCEEDINGS OF THE \\ 2019 INTERNATIONAL SUMMIT \\ OF THE \\ MUSIC \& ENTERTAINMENT \\ INDUSTRY EDUCATORS \\ ASSOCIATION}

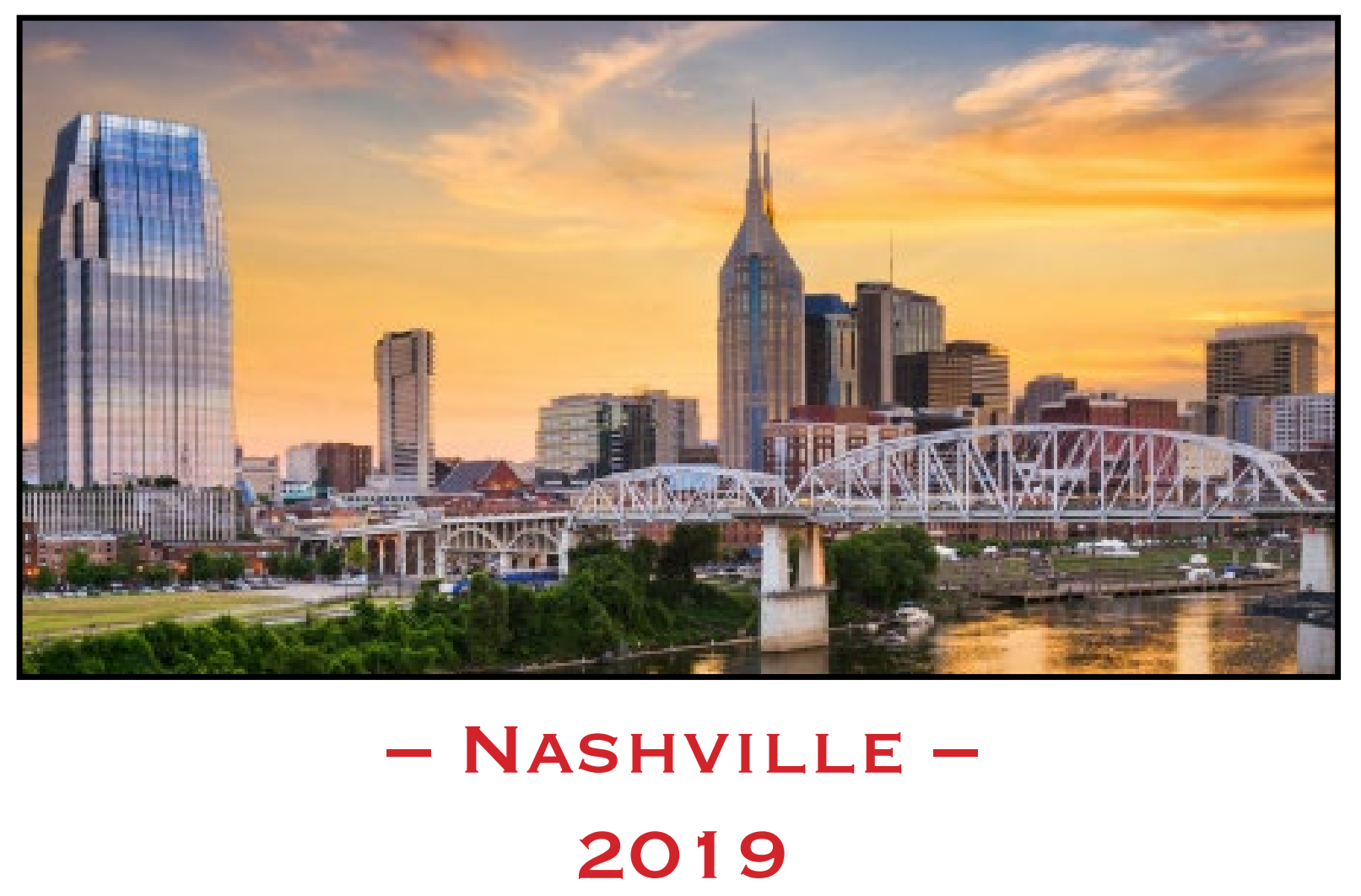

March 21 - 23, $2019 \cdot$ Belmont University - Nashville 